\title{
Dealuminated and Desilicated Natural Zeolite as a Catalyst for Hydrocracking of Used Cooking Oil into Biogasoline
}

\author{
Susi Efrina Purba, Karna Wijaya*, Wega Trisunaryanti and Remi Ayu Pratika \\ Physical Chemistry Laboratory, Chemistry Department, Universitas Gadjah Mada, Yogyakarta-55281, Indonesia
}

\begin{abstract}
The modification of natural zeolite has been conducted by dealumination and desilication using $\mathrm{HCl}$ and $\mathrm{NaOH}$ treatments as a catalyst for hydrocracking of used cooking oil into biogasoline. This research aimed to study the effect of dealumination and desilication on the natural zeolite activity and selectivity of a hydrocracking process. A variety of catalysts was prepared by applying 3,6, and $9 \mathrm{M} \mathrm{HCl}$ in the dealumination of natural zeolite to produce DNZ(3-1), DNZ(3-2) DNZ(3-3), DNZ(6-1), DNZ(6-2), DNZ(6-3), DNZ(9-1), DNZ(9-2), and DNZ(9-3) catalysts and $\mathrm{NaOH}$ in the desilication of natural zeolite to obtain NZB catalyst. The results showed that the dealumination and the desilication treatments affected the liquid product conversion of used cooking oil from catalytic hydrocracking. The hydrocracking of used cooking oil with NZB catalyst produced the highest gasoline fuel conversion of $94.87 \%$.
\end{abstract}

Keywords: natural zeolite; dealumination; desilication; hydrocracking; used cooking oil.

\section{Introduction}

Hydrocracking is a process that combines catalytic cracking and hydrogenation to convert larger hydrocarbon molecules into smaller molecules. One of the fuel fractions produced from the hydrocracking process is the gasoline fraction with $\mathrm{C}_{5}-\mathrm{C}_{12}$ hydrocarbons ${ }^{1}$. Used cooking oil can be employed to produce biogasoline through the hydrocracking process. Structurally, used cooking oils are composed of glycerides, formed out of long hydrocarbon chains that can be cracked into shorter hydrocarbon chained compounds and fuels ${ }^{2-3}$.

Zeolites are a type of acid catalyst that possess several advantages; strong acidity, high surface area, noncorrosive, environmentally safe or friendly, and easy to separate from a mixture as they make up heterogeneous catalysts. Zeolites are commonly found as a natural zeolite. Natural zeolite can be used for cracking, hydrocracking, and isomerization reactions 4,5 . The illumination process is used to remove aluminum from the zeolite framework to obtain the $\mathrm{Si} / \mathrm{Al}$ mole ratio in the desired amount. The increase of $\mathrm{Si} / \mathrm{Al}$ mole ratio can produce hydrophobic (lipophilic) zeolite with good chemical stability and strong acidity. An increase in acidity strength accompanies the increase in the amount of $\mathrm{Si} / \mathrm{Al}$ mole ratio. Dealumination process that employs strong acid can also change the properties of natural zeolite, i.e., increased $\mathrm{Si} / \mathrm{Al}$ mole ratio, reduced crystallinity, removed impurities, and increased specific surface $\operatorname{area}^{6-7}$.

*Corresponding author: Karna Wijaya

Email address: karnawijaya@ugm.ac.id

DOI: http://dx.doi.org/10.13171/mjc02101141493kw
Anggoro et al. ${ }^{8}$ reported that the zeolite $\mathrm{Y}$ dealuminated with $\mathrm{H}_{2} \mathrm{SO}_{4}$ solution of 3-8.5 $\mathrm{M}$ at temperatures of $40-67.6^{\circ} \mathrm{C}$ and reaction time of $2-6$ hours showed greater acidity and surface area than zeolite $\mathrm{Y}$ without the dealumination treatment. A larger zeolite pore diameter allows molecules to pass easier and reach the active sites ${ }^{9}$. Zeolites are materials that have a micropores structure. The small pore size can inhibit the zeolite's active site in a cracking process, causing an increased coke mass of the final product ${ }^{10}$. One technique that can be done to increase the pore diameter of a zeolite is desilication, which removes $\mathrm{Si}$ atoms from a zeolite framework by leaching with alkaline solutions. Desilication can obtain zeolite with the mesoporous structure without destroying the microporous structure of the zeolite 11,12 . While still being in control of a zeolite's $\mathrm{Si} / \mathrm{Al}$ mole ratio, acid treatment can be implemented to increase the mesoporous of a catalyst to generate better catalyst performance ${ }^{13,14}$. Peron et al. ${ }^{10}$ reported that the combined dealumination dan desilication treatments on the ZSM-5 catalyst generated new pore sizes, namely within the mesoporous range with large surface area dan pore size.

The types of zeolites that are often used in research related to zeolites are zeolite $\mathrm{Y}$ and ZMS-5, which require higher cost and energy. In this study, the zeolite used is natural zeolite from Klaten, Central Java, Indonesia. The utilization of this zeolite type has yet been developed widely, especially within the

Received November 20, 2020 Accepted December 18, 2020 Published January 14, 2021 
research field. This research aims to develop the use of natural zeolite from local sources as a catalyst, through the dealumination and desilication process, to increase its catalytic activity in the production of biogasoline from used cooking oil.

\section{Experimental}

\subsection{Catalyst preparation}

Natural zeolite (NZ) material was prepared through washing natural zeolite from Klaten, East Java, Indonesia, using distilled water followed by drying at $120^{\circ} \mathrm{C}$ for 12 hours. The dealumination and desilication processes were prepared using $\mathrm{HCl}$ (E-Merck, 37\%), NaOH (E-Merck, 99\%, Germany), $\mathrm{NH}_{4} \mathrm{Cl}$ (E-Merck, 99\%, Germany), HF (E-Merck, $40 \%$, Germany), $\mathrm{HNO}_{3}$ (E-Merck, 65\%, Germany) and $\mathrm{NH}_{3}$ (E-Merck, 25\%, Germany). The dealumination of natural zeolites was done by mixing $6 \mathrm{~g}$ of the natural zeolite into $100 \mathrm{~mL} \mathrm{HCl}$ solutions of 3,6, and $9 \mathrm{M}$ concentrations at a temperature of $90^{\circ} \mathrm{C}$ with time variations of 1,2 , and 3 hours. The obtained zeolite was washed with distilled water to remove $\mathrm{Cl}^{-}$ions, followed by drying at $120^{\circ} \mathrm{C}$ and calcination at $550^{\circ} \mathrm{C}$ for 5 hours with air supply and denoted as (DNZ), DNZ(3-1), DNZ(3-2) DNZ(3-3), DNZ(6-1), DNZ(6-2), DNZ(6-3), DNZ(9-1), DNZ(9-2), DNZ(9-3) ( $\mathrm{HCl}$ concentrations of 2, 6 and $9 \mathrm{M}$; variations of time of 1,2 , and 3 hours).

The desilication of natural zeolite was prepared by the dealuminated natural zeolite (DNZ) with the highest $\mathrm{Si} / \mathrm{Al}$ mole ratio that treatment using $0.5 \mathrm{M} \mathrm{NaOH}$ at $27^{\circ} \mathrm{C}$ for 30 minutes. The solid obtained was washed using distilled water with a mole ratio of 1:30 until it reached a neutral $\mathrm{pH}$. The catalysts were then dried at a temperature of $120^{\circ} \mathrm{C}$, calcined at $550^{\circ} \mathrm{C}$ for 5 hours, and denoted as desilicated natural zeolite (NZB).

\subsection{Catalytic test}

The thermal hydrocracking process of used cooking oil obtained from a fried chicken business in Sleman regency, D.I. Yogyakarta, Indonesia, was carried out at 325,350 , and $375^{\circ} \mathrm{C}$ for 1 hour to determine the optimum hydrocracking temperature under hydrogen gas flow conditions $(10 \mathrm{~mL} / \mathrm{min})$ with a ratio of feed to the catalyst of $1: 100$. The thermal hydrocracking process was carried out using a hydrocracking microreactor as a flow reactor system (Figure 1). The compositions of the liquid products obtained were analyzed using GC-MS.

The products percentage were determined using the formula:

Liquid fraction $(w t \%)=\frac{\text { liquid }(\mathrm{g})}{\text { feed }(\mathrm{g})} \times 100 \%$

Where liquid is the product mass-produced from the hydrocracking process, and feed is the mass of feed.

The selectivity of liquid product was determined using the formula:

Gasoline fraction $(\mathrm{wt} \%)=\mathrm{C}_{5}-\mathrm{C}_{12}$ fraction $\mathrm{x}$ liquid fraction (wt $\%$ )

Diesel fraction $(\mathrm{wt} \%)=\mathrm{C}_{13}-\mathrm{C}_{22}$ fraction $\mathrm{x}$ liquid fraction (wt\%)

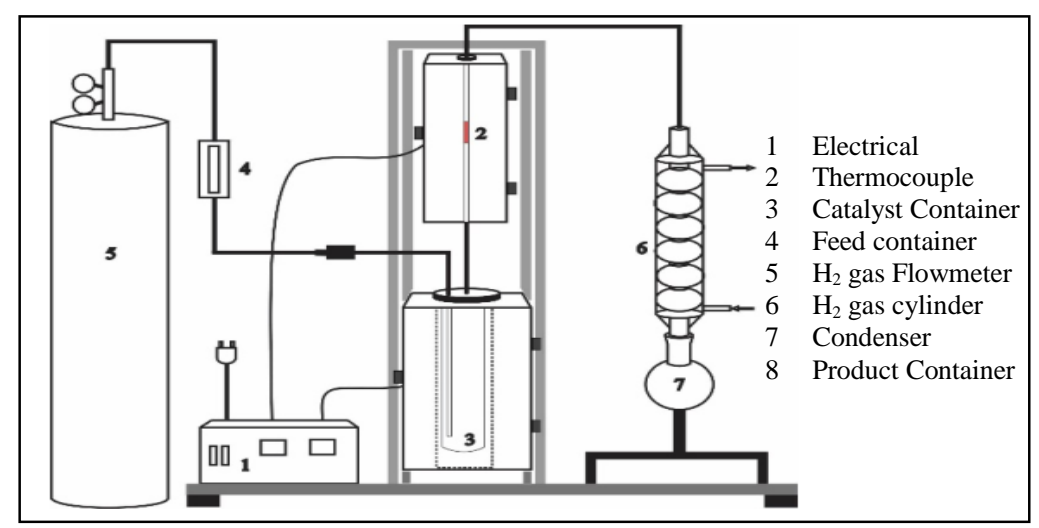

Figure 1. Hydrocracking Microreactor

\subsection{Catalyst characterization}

Characterizations of NZ, DNZ, DNZ(3-1), DNZ(3-2)

DNZ(3-3), DNZ(6-1), DNZ(6-2), DNZ(6-3), DNZ(9-1), DNZ(9-2), DNZ(9-3) and NZB catalysts were conducted with X-ray Diffraction (PANalytical $\mathrm{X}$ 'Pert Pro) using monochromatized $\mathrm{CuK} \alpha$ radiation $(\mathrm{K} \alpha=1.505 \AA, 40 \mathrm{~mA})$, scanned in the $2 \theta 5-90^{\circ}$ range. Fourier Transform Infrared Spectra of samples were collected from FTIR (8201PC, Shimadzu) studied in the $400-4000 \mathrm{~cm}^{-1}$ wavenumber range, employing the $\mathrm{KBr}$ disc technique. Surface Area Analysis of samples was done using Surface Area
Analyzer (Quadrasorb EVO/SI) with BrunauerEmmet-Teller (BET) from $\mathrm{N}_{2}$ gas adsorption isotherms measured at $77 \mathrm{~K}$.

Coupled plasma atomic emission spectroscopy analysis was done using ICP-AES analyzer (Shimadzu ICPE-9820), and $\mathrm{Si} / \mathrm{Al}$ mole ratio analysis was done using an equivolumetric mixture of $\mathrm{HF}$ (40 wt $\%$ in water), $\mathrm{HNO}_{3}$ (65 wt $\%$ in water), and water to dissolve the zeolites completely. The acidity of the catalyst samples was analyzed through the gravimetric method using ammonia adsorption. Hydrocracking products were analyzed using Gas 
Chromatography-Mass Spectroscopy (Shimadzu QP2010S) with Rtx 5 MS column, column length of $30 \mathrm{~m}$, helium carrier gas, and $\mathrm{EI} 70 \mathrm{eV}$.

\section{Results and Discussion}

\subsection{Effect of dealumination on $\mathrm{Si} / \mathrm{Al}$ mole ratio of} natural zeolite

Identification of the increase in the $\mathrm{Si} / \mathrm{Al}$ mole ratio was made using FTIR analysis shown in Figure 2. Absorption peak appears in the wavenumbers around $3456 \mathrm{~cm}^{-1}$ and $1635 \mathrm{~cm}^{-1}$, indicating $\mathrm{O}-\mathrm{H}$ stretching and bending vibrations due to water molecules' presence coordinated onto the catalyst ${ }^{15}$. Peaks at wavenumber $1150-1050 \mathrm{~cm}^{-1}$ were observed, denoting asymmetrical stretching vibrations of T-O-T ( $\mathrm{T}=\mathrm{Si}$ or $\mathrm{Al})$, whereby before treatment with acid, the T-O-T bond showed Si-O-Al bond at $1049 \mathrm{~cm}^{-1}$. While after the treatment, spectra T-O-T shifted to 1080-1095 $\mathrm{cm}^{-1}$ indicating Si-O-Si ${ }^{16}$. This phenomenon showed that the Si-O-Si bond's strength was more than that of the Si-O-Al bond after treatment with acid. The higher the $\mathrm{HCl}$ concentration, the higher the absorption intensities that appeared in wavenumbers $794 \mathrm{~cm}^{-1}$ and $462 \mathrm{~cm}^{-1}$, both denoting Si-O vibration, implying an increase in the quartz group $(\mathrm{Si}-\mathrm{O})$ at higher $\mathrm{HCl}$ concentrations. This showed that the dealumination process on natural zeolite was successfully carried out.

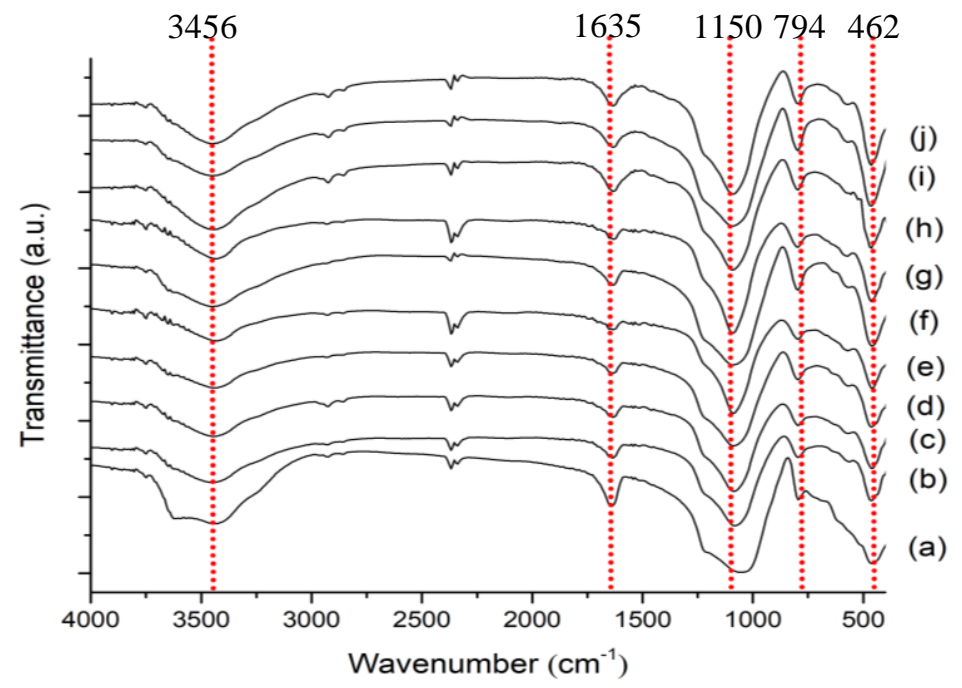

Figure 2. FTIR spectra of NZ (a), DNZ(3-1) (b), DNZ(3-2) (c), DNZ(3-3) (d), DNZ(6-1) (e), DNZ(6-2) (f), DNZ(6-3) (g), DNZ(9-1) (h), DNZ(9-2) (i) and DNZ(9-3) (j)

An analysis with inductively coupled plasma atomic emission spectroscopy (ICP-AES) was carried out to confirm the successful dealumination of the natural zeolite. The concentration of $\mathrm{Si}$ and $\mathrm{Al}$ atoms and the $\mathrm{Si} / \mathrm{Al}$ mole ratio are presented in Table 1.

Table 1. Si/Al mole ratios, before and after dealumination.

\begin{tabular}{|c|c|c|c|}
\hline Sample & {$[\mathrm{Si}](\mathrm{mmol} / \mathrm{L})$} & {$[\mathrm{Al}](\mathrm{mmol} / \mathrm{L})$} & Si/Al mole ratio \\
\hline NZ & 0.49 & 0.23 & 2.13 \\
\hline DNZ (3-1) & 0.60 & 0.20 & 3.00 \\
\hline DNZ (3-2) & 0.53 & 0.16 & 3.31 \\
\hline DNZ (3-3) & 0.55 & 0.15 & 3.66 \\
\hline DNZ (6-1) & 0.61 & 0.14 & 4.36 \\
\hline DNZ (6-2) & 0.64 & 0.12 & 5.33 \\
\hline DNZ (6-3) & 0.59 & 0.13 & 4.54 \\
\hline DNZ (9-1) & 0.45 & 0.08 & 5.62 \\
\hline DNZ (9-2) & 0.38 & 0.06 & 6.33 \\
\hline DNZ (9-3) & 0.42 & 0.08 & 5.30 \\
\hline
\end{tabular}

Generally, an increase in $\mathrm{HCl}$ concentration caused $\mathrm{Si} / \mathrm{Al}$ mole ratio to increase due to the increasing number of $\mathrm{Al}$ removed from the zeolite framework.
However, longer treatment times do not always produce dealuminated zeolite with a higher $\mathrm{Si} / \mathrm{Al}$ mole ratio. The longer reaction time in the high acid 
concentration led $\mathrm{HCl}$ to attack $\mathrm{Si}$ atoms and reduce the $\mathrm{Si} / \mathrm{Al}$ mole ratio. The highest $\mathrm{Si} / \mathrm{Al}$ mole ratio of zeolite was obtained from the dealumination using $\mathrm{HCl} 9 \mathrm{M}$ for 2 hours, namely $\mathrm{DNZ}(9-2) . \mathrm{HCl}$ in high concentration can release $\mathrm{Al}$ from zeolite and cause the $\mathrm{Si} / \mathrm{Al}$ ratio to increase ${ }^{8}$. The $\mathrm{Si} / \mathrm{Al}$ mole ratio of DNZ (9-2) was 6.33, whereas the natural zeolite had $\mathrm{Si} / \mathrm{Al}$ ratio of 2.13 . This showed that the dealumination process had successfully increased the $\mathrm{Si} / \mathrm{Al}$ mole ratio of the zeolite.

\subsection{Effect of dealumination and desilication on the crystallinity of natural zeolite}

The diffractograms of natural zeolites and zeolites after dealumination are presented in Figure 3. The types of natural zeolites in different regions are distinct because the natural conditions influence them. Based on the XRD analysis, the natural zeolite in this study contained mordenite (PDF no. 049-0924) and clinoptilolite (PDF no. 022-1236), the dominant phases. The dealuminated zeolite (DNZ(9-2)) with the highest $\mathrm{Si} / \mathrm{Al}$ ratio was characterized for its crystallinity. It was found that the crystallinity of the natural zeolite after the dealumination process slightly decreased, seen from the peak at $2 \theta=23.1$ (Clipnotilolite, mordenite). The decrease in crystallinity was due to the loss of $\mathrm{Al}$ atoms from the zeolite framework ${ }^{9}$.

The desilication of the natural zeolite (NZ) and the dealuminated zeolite with the highest $\mathrm{Si} / \mathrm{Al}$ mole ratio (DNZ(9-2)) was carried out with $\mathrm{NaOH}$ treatment. After desilication, the desilicated natural zeolite (NZB) was also found to have decreased. Desilication treatment with $\mathrm{NaOH}$ can generate leaching of the solid structure and the dissolution of the crystalline structure of zeolite ${ }^{16}$. The diffractograms of the dealuminated natural zeolite (DNZ(9-2)), dealuminated and desilicated natural zeolite (DNZ(9-2)B), and desilicated natural zeolite (NZB) showed the same crystalline structure.

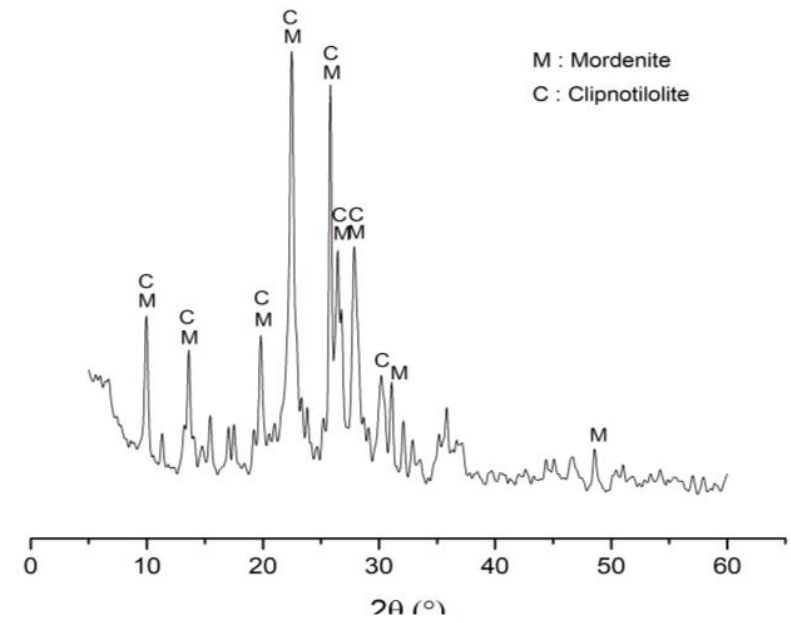

(a)

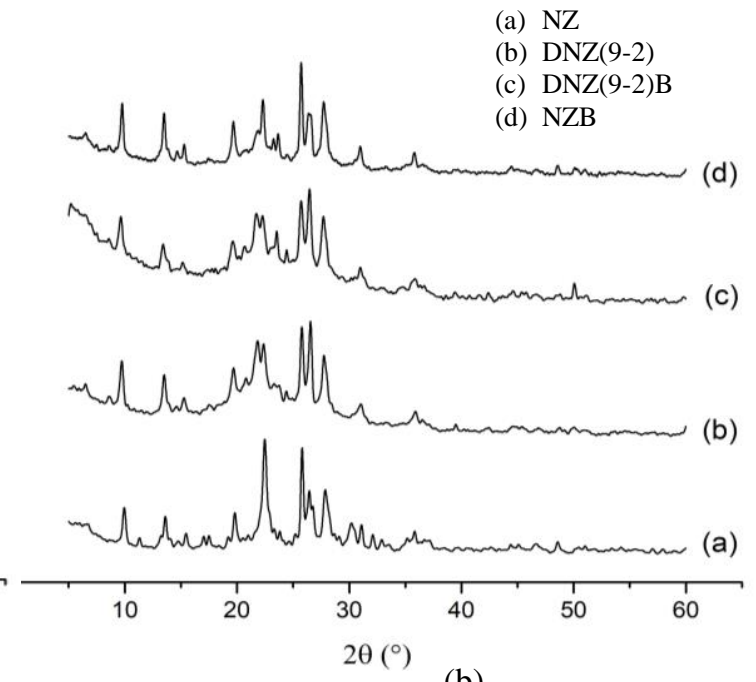

(b)

Figure 3. Diffractograms of (a) natural zeolite and (b) NZ, DNZ(9-2), DNZ(9-2)B and NZB

\subsection{Effects of desilication on the acidity of natural zeolites}

Acidity test of NZ, DNZ(9-2), DNZ(9-2)B, and NZB was carried out by ammonia adsorption test to show $\mathrm{NH}$ groups' interactions with samples. In this method, the total number of acid sites in the models is assumed to be equivalent to the amount of ammonia absorbed. The acid sites in the samples consist of Brønsted acid sites and Lewis acid sites. The results of the acidity test of natural zeolite are shown in Table 2. The existence of these two acid sites could also be identified through FTIR analysis shown in Figure 4.

Ammonia coordination bonds at Lewis acid sites produce new vibrations at $1080-1118 \mathrm{~cm}^{-1}$, which is the bending symmetry of $\mathrm{NH}_{3}$ coordinated onto Lewis acid sites. The absorption of ammonia at Brønsted acid can be identified in wavenumbers $1396-1404 \mathrm{~cm}^{-1}$ due to the $-\mathrm{NH}$ asymmetric stretching vibration from bonding with Brønsted acid sites the samples ${ }^{17}$. The acidity of natural zeolite increased after dealumination and/or desilication.

Desilicated natural zeolite (NZB) shows the highest intensity of ammonia absorption at Lewis and Brønsted acid sites with an acidity value of $4.40 \mathrm{mmol} / \mathrm{g}$ due to the formation of Brønsted acid sites through the exchange of metal ions with $\mathrm{H}$ ions by $\mathrm{HCl}$ treatment. Moreover, Lewis sites were also formed due to the extraction of aluminum atoms from the inside to the outside of the zeolite framework ${ }^{18}$. 
Table 2. The acidity of natural zeolites.

\begin{tabular}{|c|c|}
\hline Sample & Acidity $(\mathrm{mmol} / \mathrm{g})$ \\
\hline NZ & 0.51 \\
\hline DNZ(9-2) & 3.76 \\
\hline DNZ(9-2)B & 2.48 \\
\hline NZB & 4.40 \\
\hline
\end{tabular}

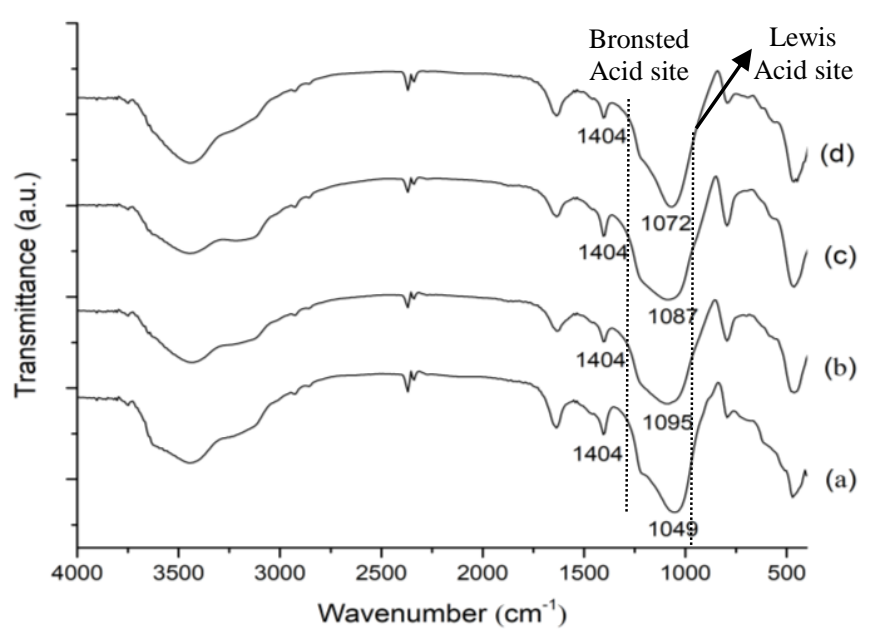

Figure 4. FTIR spectra of (a) NZ, (b) DNZ(9-2), (c) DNZ(9-2)B and (d) NZB after ammonia adsorption

\subsection{Effects of desilication on the pore size of natural zeolites}

The material's pore characteristic is essential to analyze, specifically the surface area, pore diameter, and pore volume of samples. Analysis of samples' porosity was carried out with gas sorption analyzer (GSA) by adsorption and desorption of Nitrogen $\left(\mathrm{N}_{2}\right)$ gas. Based on Table 3, natural zeolite pore characteristics after dealumination and desilication showed an increase in the total pore volume and surface area. The natural zeolite had a surface area of $75.33 \mathrm{~m}^{2} / \mathrm{g}$; after the dealumination process, the specific area of the natural zeolite increased to $178.5 \mathrm{~m}^{2} / \mathrm{g}$, whereas after the desilication process, it increased to $162.4 \mathrm{~m}^{2} / \mathrm{g}$. The formation of secondary pores caused these increases after being treated with acid and/or base. Meanwhile, the average pore diameter of natural zeolite decreased after acid and/or base treatments due to the opening of micropores and secondary pores, forming in the form of micropores. Hence, the zeolite pores' size after being treated with acid and/or base decreased because of the increased contribution of the micropore to the zeolites. The total pore volume of the Natural zeolite (NZ) also increased after dealumination and desilication. Natural zeolite has a low total pore volume due to a low $\mathrm{Si} / \mathrm{Al}$ mole ratio $(2.13 \%)$. Alkaline treatment on dealuminated natural zeolite (DNZ(9-2)) generated a high $\mathrm{Si} / \mathrm{Al}$ mole ratio and increased pore diameter size ${ }^{19,20}$. This condition showed the importance of the $\mathrm{Si} / \mathrm{Al}$ mole ratio as a success factor of desilication with alkaline treatment. Si/Al mole ratios and changes in pore diameter size of samples are shown in Table 4.

The adsorption/desorption isotherms of the natural zeolites before and after treatments with $\mathrm{HCl}$ (dealumination process) and $\mathrm{NaOH}$ (desilication process) are shown in Figure 5. The type of adsorption-desorption isotherm of the samples is type IV isotherm, indicating that the materials are mesoporous with a 2-50 $\mathrm{nm}$ (Table 3). The hysteresis pattern provided that the NZ, DNZ(9-2), DNZ(9-2)B, and NZB samples showed $\mathrm{H} 4$ type hysteresis. This hysteresis type explains narrow slit pores with irregular internal cavity shapes and extensive pore size distribution ${ }^{17}$. Al and $\mathrm{Si}$ atoms' extraction causes the non-homogeneous cavity carried out by acid and base treatment without using templates.

Table 3. Pore characteristics of zeolites.

\begin{tabular}{|c|c|c|c|c|}
\hline \multirow{2}{*}{ Parameter } & \multicolumn{4}{|c|}{ Sample } \\
\cline { 2 - 5 } & NZ & DNZ(9-2) & DNZ(9-2)B & NZB \\
\hline Average pore diameter $(\mathrm{nm})$ & 6.53 & 4.18 & 5.55 & 4.27 \\
\hline Surface area $\left(\mathrm{m}^{2} / \mathrm{g}\right)$ & 75.33 & 178.50 & 142.10 & 162.40 \\
\hline Total pore volume $(\mathrm{mL} / \mathrm{g})$ & 0.123 & 0.186 & 0.197 & 0.173 \\
\hline
\end{tabular}


Table 4. Correlation of $\mathrm{Si} / \mathrm{Al}$ ratio with pore diameter before and after desilication.

\begin{tabular}{|c|c|c|c|}
\hline Sample & Si/Al mole ratio & Initial pore diameter $(\mathrm{nm})$ & Desilicated pore diameter $(\mathrm{nm})$ \\
\hline NZ & 2.13 & 6.53 & 4.27 \\
\hline DNZ(9-2) & 6.33 & 4.18 & 5.55 \\
\hline
\end{tabular}
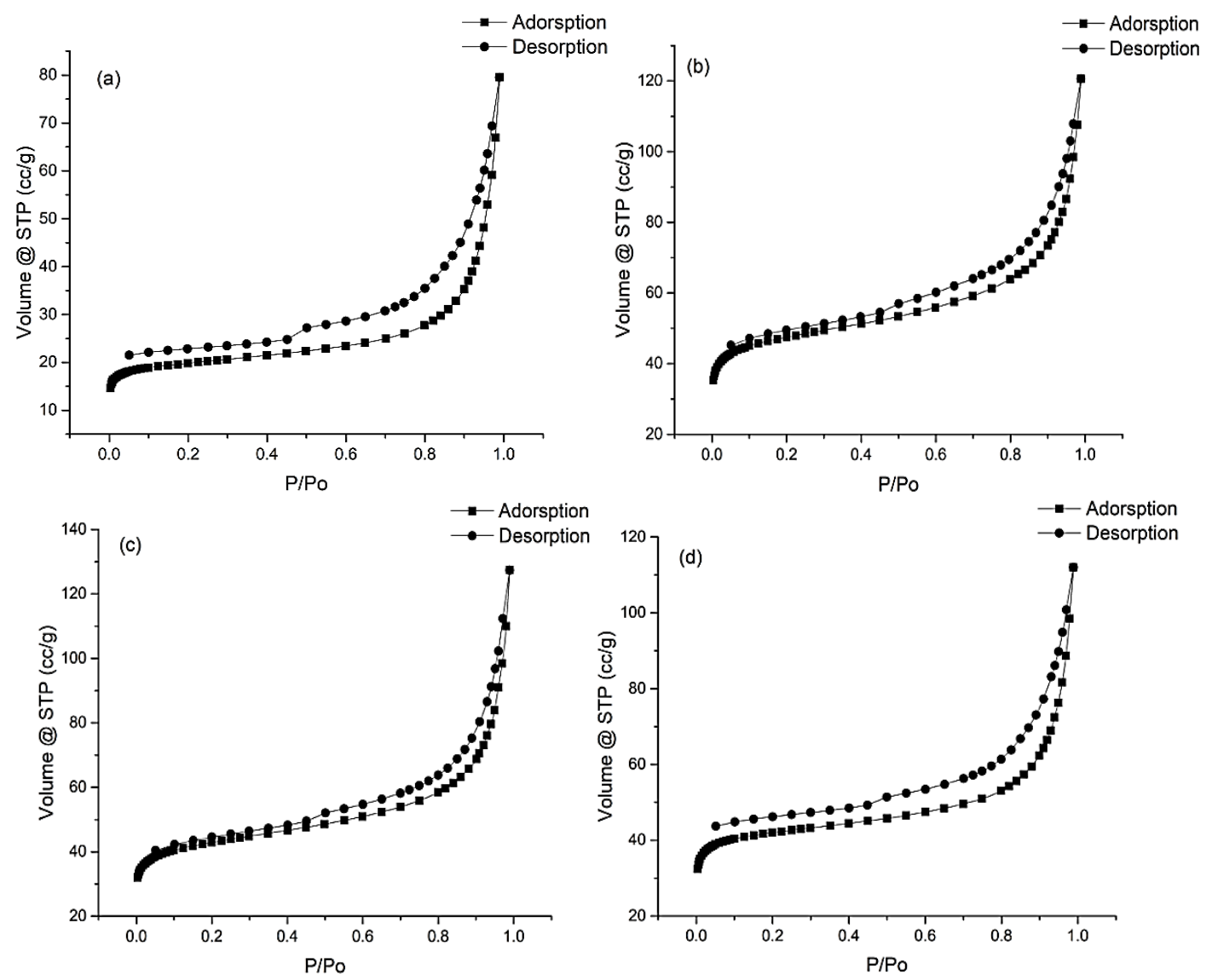

Figure 5. Isothermal curves of (a) NZ, (b) DNZ(9-2), (c) DNZ(9-2)B, and (d) NZB

\subsection{Hydrocracking of used cooking oil}

The composition of used cooking oil was determined from GC-MS analysis, as shown in Table 5. The used cooking oil consisted of $\mathrm{C}_{16}$ and $\mathrm{C}_{18}$ compounds that have good fuel production potential by hydrocracking process. The optimum hydrocracking temperature was determined experimentally by choosing the highest conversion of liquid product from hydrocracking without the catalyst.

It was found that the optimum temperature was $350^{\circ} \mathrm{C}$ with a liquid product conversion of $14.5 \%$. The catalytic activity of each catalyst sample can be determined from the catalytic hydrocracking conversion. The conversions of liquid products produced by the catalysts are shown in Figure 6, Table 6.

Table 5. Used cooking oil composition based on GC-MS.

\begin{tabular}{|c|c|c|}
\hline Compound name & Chemical Formula & Composition (\%) \\
\hline Hexadecanoic acid & $\mathrm{C}_{16} \mathrm{H}_{32} \mathrm{O}_{2}$ & 34.79 \\
\hline 9,12-hexadecadienoic acid & $\mathrm{C}_{16} \mathrm{H}_{28} \mathrm{O}_{2}$ & 25.34 \\
\hline 10 -octadecanoic acid & $\mathrm{C}_{18} \mathrm{H}_{34} \mathrm{O}_{2}$ & 34.60 \\
\hline Octadecanoic acid & $\mathrm{C}_{18} \mathrm{H}_{36} \mathrm{O}_{2}$ & 5.28 \\
\hline
\end{tabular}




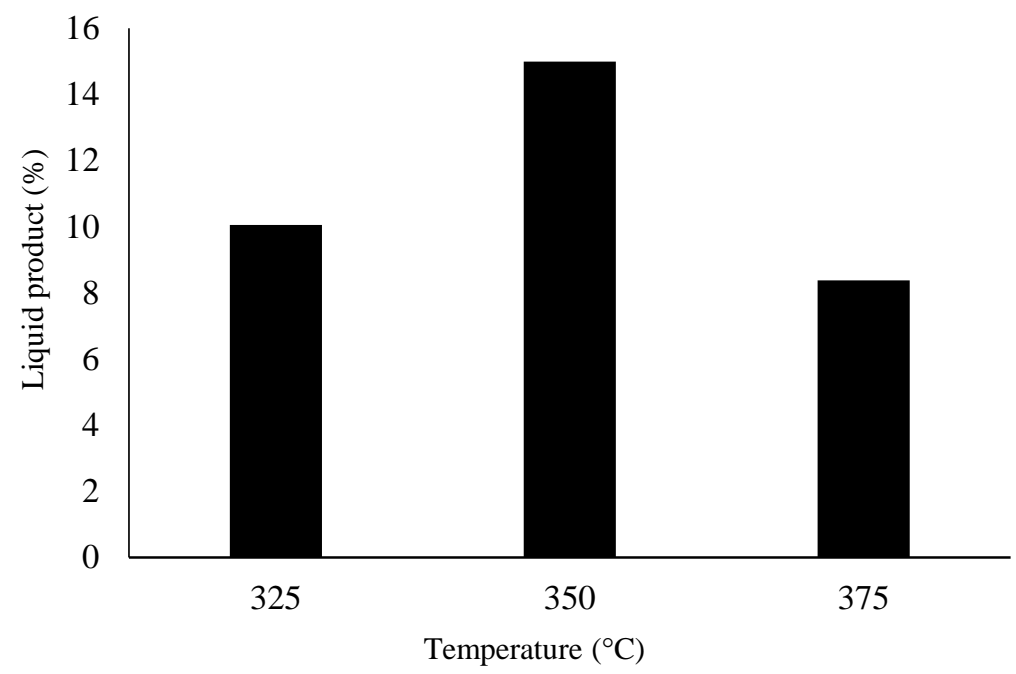

Figure 6. Liquid product conversion from the hydrocracking of used cooking oil without catalyst under hydrogen gas flow condition $(10 \mathrm{~mL} / \mathrm{min})$ with a ratio of feed to the catalyst 1:100 for 1 hour

Table 6. Liquid product conversion of used cooking oil from catalytic hydrocracking at $350^{\circ} \mathrm{C}$.

\begin{tabular}{|c|c|}
\hline Catalyst & Liquid product (\%) \\
\hline without catalyst & 15.3 \\
\hline NZ & 19.9 \\
\hline $\mathrm{NZ}(9-2)$ & 22.7 \\
\hline D $\quad \mathrm{NZ}(9-2) \mathrm{B}$ & 16.9 \\
\hline NZB & 43.5 \\
\hline
\end{tabular}

Overall, the conversions of liquid products that employed catalysts were smaller than the product without the catalyst. The small number of conversions was due to the formation of coke in the presence of the catalysts. The factors that affect the catalyst's selectivity are reaction operating conditions and the catalyst properties, such as active sites, particle size, and chemical composition. The catalyst can contain impurities such as heavy metal residue, which can decrease its catalytic activity ${ }^{21}$.

Liquid product distribution consists of hydrocarbon in the $\mathrm{C}_{5}-\mathrm{C}_{12}$ range (gasoline) and $\mathrm{C}_{13}-\mathrm{C}_{22}$ range (diesel), respectively ${ }^{3}$. The other lower carbon compounds, such as methanol and ethanol, were also found. The percentages of the selectivity of used cooking oil in the hydrocracking products are presented in Table 7.

Table 7. The selectivity of liquid product from catalytic hydrocracking.

\begin{tabular}{|c|c|c|c|}
\hline Catalyst & Gasoline fraction $(\%)$ & Diesel fraction (\%) & Others $(\%)$ \\
\hline without catalyst & 57.94 & 6.34 & 35.72 \\
\hline NZ & 66.15 & 8.76 & 25.09 \\
\hline DNZ(9-2) & 94.20 & 2.34 & 3.46 \\
\hline DNZ(9-2)B & 86.47 & 13.53 & 0 \\
\hline NZB & 94.87 & 5.13 & 0 \\
\hline
\end{tabular}

The obtained gasoline fractions that employed treated zeolite catalyst with acid and/or base were generally higher than the process with just natural zeolite catalyst. The increasing acidity of the catalysts causes this after dealumination and desilication treatments. The catalysts' acid sites are the active sites involved in the cracking process, meaning that catalysts' catalytic activity and selectivity can increase with increasing acidity. Moreover, the surface area and pore size of the treated zeolites also support the results. Surface area and pore size can increase the interaction between the catalyst and the feed ${ }^{22,23}$. However, comparatively, acidity played a more critical role, as proven from the results of DNZ(9-2) and NZB. NZB had higher acidity and a lower surface area than DNZ(9-2), but the activity and selectivity were higher than DNZ(9-2) with a higher surface area. Based on the liquid product's selectivity, the highest gasoline fraction was obtained from the catalyst NZB with an 
amount of $94.87 \%$, which can be attributed to its acidity - the highest among the catalysts made.

Lastly, the gasoline compositions from the hydrocracking products of all catalysts are shown in Table 8. NZB catalyst showed the highest gasoline fraction, which was almost similar to DNZ(9-2) catalyst, at $94.20 \%$; catalyst with the high acidity and pore size (NZB) showed the highest gasoline fraction. However, the DNZ(9-2) with the high surface area and small pore size also have a high gasoline fraction. The composition of gasoline product from the hydrocracking product using NZB catalyst with the highest gasoline fraction yield is shown in Table 9. The gasoline product's main composition consisted of toluene $\left(\mathrm{C}_{7} \mathrm{H}_{8}, 14.09 \%\right)$ and benzene $\left(\mathrm{C}_{6} \mathrm{H}_{6}, 6.25 \%\right)$.

Table 8. Catalyst selectivity to gasoline fraction.

\begin{tabular}{|c|c|c|c|c|}
\hline Catalyst & Acidity & Surface area & Pore size & Gasoline fraction (\%) \\
\hline NZ & 0.51 & 75.33 & 6.53 & 66.15 \\
\hline DNZ(9-2) & 3.76 & 178.55 & 4.18 & 94.20 \\
\hline DNZ(9-2)B & 2.48 & 162.40 & 4.72 & 86.47 \\
\hline NZB & 4.40 & 160.60 & 4.91 & 94.87 \\
\hline
\end{tabular}

Table 9. Composition of gasoline product from hydrocracking using NZB catalyst.

\begin{tabular}{|c|c|c|}
\hline Compound name & Chemical Formula & Composition (\%) \\
\hline Hexane & $\mathrm{C}_{6} \mathrm{H}_{14}$ & 0.94 \\
\hline Benzene & $\mathrm{C}_{6} \mathrm{H}_{6}$ & 6.25 \\
\hline 1-Heptane & $\mathrm{C}_{7} \mathrm{H}_{14}$ & 0.7 \\
\hline Heptane & $\mathrm{C}_{7} \mathrm{H}_{16}$ & 1.82 \\
\hline Toluene & $\mathrm{C}_{7} \mathrm{H}_{8}$ & 14.09 \\
\hline 1-Octane & $\mathrm{C}_{8} \mathrm{H}_{16}$ & 2.38 \\
\hline Octane & $\mathrm{C}_{8} \mathrm{H}_{18}$ & 4.4 \\
\hline Ethylbenzene & $\mathrm{C}_{8} \mathrm{H}_{10}$ & 1.97 \\
\hline 1-Nonane & $\mathrm{C}_{9} \mathrm{H}_{18}$ & 4.4 \\
\hline Nonane & $\mathrm{C}_{9} \mathrm{H}_{20}$ & 6.05 \\
\hline Decane & $\mathrm{C}_{10} \mathrm{H}_{22}$ & 2.24 \\
\hline Undecane & $\mathrm{C}_{11} \mathrm{H}_{24}$ & 2.01 \\
\hline 2-Undecane & $\mathrm{C}_{11} \mathrm{H}_{22}$ & 1.31 \\
\hline Dodecane & $\mathrm{C}_{12} \mathrm{H}_{26}$ & 1.56 \\
\hline 1-Dodecene & $\mathrm{C}_{12} \mathrm{H}_{24}$ & 2.01 \\
\hline & & \\
\hline & & \\
\hline
\end{tabular}

\section{Conclusion}

The dealumination and/or desilication of natural zeolite have successfully been carried out. The dealumination and/or desilication conducted increased the acidity and surface area of natural zeolite. The dealumination process involving a high $\mathrm{HCl}$ concentration had generated a higher $\mathrm{Si} / \mathrm{Al}$ mole ratio whereby the highest $\mathrm{Si} / \mathrm{Al}$ mole ratio of zeolite was obtained from DNZ(9-2) with a mole ratio of 6.33. The desilication process increased the specific surface area of natural zeolite from 75.33 to $162.4 \mathrm{~m}^{2} / \mathrm{g}$. Hydrocracking of used cooking oil with natural zeolite catalyst treated with dealumination and/or desilication showed increased selectivity towards gasoline products, specifically using NZB catalyst with a gasoline selectivity value of $94.87 \%$.

\section{Acknowledgment}

The authors would like to thank the Research Directorate of Universitas Gadjah Mada for assisting in funding this research through the Rekognisi Tugas Akhir (RTA) 2019.

\section{References}

1- S. Bezergianni, S. Voutetakis, A. Kalogianni, Catalytic hydrocracking of fresh and used cooking oil, Ind. Eng. Chem. Res., 2009, 48, 8402-8406.

2- Z. Zhang, Q. Wang, H. Chen, X. Zhang, Hydroconversion of waste cooking oil into green biofuel over hierarchical USY-supported NiMo catalyst: a comparative study of desilication and dealumination, Catalysts, 2017, 7, 281. 
3- M. Utami, K. Wijaya, W. Trisunaryanti, Ptpromoted sulfated zirconia as a catalyst for hydrocracking of LDPE plastic waste into liquid fuels, Mater. Chem. Phys., 2018, 213, 548-555.

4- G. A. Nasser, T. Kurniawan, T. Tago, I. A. Bakare, T. Taniguchi, Y. Nakasaka, T. Masuda, O. Muraza, Cracking of $n$-hexane over hierarchical MOR zeolites derived from natural minerals, J. Taiwan Inst. Chem. Eng., 2016, 61, 20-25.

5- S. Kadarwati, F. Rahmawati, P. E. Rahayu, K. I. Supardi, Kinetics and mechanism of Ni/Zeolitecatalyzed hydrocracking of palm oil into Biofuel, Indones, J. Chem., 2017, 13, 77-85.

6- L. E. Burris, M. C. G. Juenger, the effect of acid treatment on the reactivity of natural zeolites used as supplementary cementitious materials, Cem. Concr. Res., 2015, 79, 185-193.

7- M. Silva, A. Lecus, Y. Lin, J. Corrao, tailoring natural zeolites by acid treatments, J. Mater. Sci. Chem. Eng., 2009, 7, 26-37.

8- D. D. Anggoro, H. Oktavianty, S. B. Sasongko, L. Buchori, Effect of dealumination on the acidity of zeolite $\mathrm{Y}$ and the yield of glycerol monostearate (GMS), Chemosphere, 2020, 257, 127012.

9- X. Chen, W. V. Srubar, Sulfuric acid improves the reactivity of zeolites via dealumination, Constr. Build Maters., 2020, 264, 120648.

10-D. V. Peron, V. L. Zholobenko, J. H. S. Melo, M. Capron, N. Nuns, M. O. Souza, L. A. Feris, N. R. Marcilio, V. V. Ordomsky, A. Y. Khodakov, External surface phenomena in dealumination and desilication of a large single crystal of ZSM-5 zeolite synthesized from a sustainable source, Microporous and Mesoporous Mater., 2019, 286, 57-64.

11-Y. Wu, F. Tian, J. Liu, D. Song, C. Jia, Y. Chen, Enhanced catalytic isomerization of $\alpha$-pinene over mesoporous zeolite beta of low $\mathrm{Si} / \mathrm{Al}$ ratio by $\mathrm{NaOH}$ treatment, Microporous Mesoporous Mater., 2017, 162, 168-174.

12-J. C. Groen, T. Sano, J. A. Moulijn, J. PérezRamírez, Alkaline-mediated mesoporous mordenite zeolites for acid-catalyzed conversions, J. Catal., 2007, 251, 21-27.

13-M. H. M. Ahmed, O. Muraza, M. Yoshioka, T. Yokoi, Effect of multi-step desilication and dealumination treatments on the performance of hierarchical EU-1 zeolite for converting methanol to olefins, Microporous Mesoporous Mater., 2017, 241, 79-88.

14-K. Góra-Marek, K. Tarach, J. Tekla, Z. Olejniczak, P. Kü̈trowski, L. Liu, J. Martinez-
Triguero, F. Rey, Hierarchical mordenite dedicated to the fluid catalytic cracking process: Catalytic performance regarding textural and acidic properties, J. Phys. Chem. C., 2014, 118, 28043-28054.

15-S. Ardizzone, C. L. Bianchi, G. Cappelletti, F. Porta, Liquid-Phase catalytic activity of sulfated zirconia from sol-gel precursors: The role of the surface feature, J. Catal., 2004, 227, 470-478.

16-J. V. Milato, R. J. Franca, A. S. Rocha, M. R. C. M. Calderari, Catalytic co-pyrolysis of oil sludge with HDPE to obtain paraffinic products over HUSY zeolites prepared by dealumination and desilication, J. Anal. Appl. Pyrolysis., 2020, 151, 104928.

17-M. S. Ore, K. Wijaya, W. Trisunaryanti, W. D. Saputri, E. Heraldy, M. W. Yuwana, P. L. Hariani, A. Budiman, S. Sudiono, The synthesis of $\mathrm{SO}_{4} / \mathrm{ZrO}_{2}$ and $\mathrm{Zr} / \mathrm{CaO}$ catalysts via hydrothermal treatment and their application for conversion of low-grade coconut oil into biodiesel, J. Environ. Chem. Eng., 2020, 8, 104205.

18-P. P. Dik, G. G. Danilova, M. O. Kazakov, K. A. Nadiena, V. Budukva, P. Yu, O. V. Klimov, P. P. Prosvirin, E. Y. Gerasimov, T. O. Bok, E. E. Dobryakova, E. E. Knyazeva, I. I. Ivanova, A. S. Noskov, Hydrocracking of vacuum gas oil over $\mathrm{NiMo} /$ zeolite- $\mathrm{Al}_{2} \mathrm{O}_{3}$ : Influence of zeolite properties, Fuel, 2019, 237.

19-N. Viswanadham, M. Kumar, Effect of dealumination severity on the pore size distribution of mordenite, Microporous Mesoporous Mater., 2006, 92, 31-37.

20-Z. Qin, W. Shen, S. Zhou, Y. Shen, C. Li, P. Zeng, B. Shen, Defect-assisted mesopore formation during Y zeolite dealumination: The types of defect matter, Microporous and Mesoporous Mater., 2020, 303, 110248.

21-C. T. Tye, Catalysts for hydroprocessing of heavy oils and petroleum residues, Intechopen, 2019. doi: 10.5772/intechopen. 89451.

22-W. Sriningsih, M. G. Saerodji, W. Trisunaryanti, Triyono, R. Armunanto, I. I. Falah, Fuel production from LDPE plastic waste over natural zeolite supported Ni, Ni-Mo, Co and Co-Mo metals, Procedia Environ. Sci., 2014, 20, 215-224.

23-Q. Cui, S. Wang, Q. Wei, L. Mu, G. Yu, T. Zhang, Y. Zhou, Synthesis and characterization of $\mathrm{Zr}$ incorporated small crystal size Y zeolite supported NiW catalysts for hydrocracking of vacuum gas oil, Fuel, 2019, 237, 597-605. 